melaninogenicus and Bacteroides fragilis groups in mixed infections. Infect Immun 1984;44:12-15

8. Brook I. Effect of Streptococcus faecalis on the growth of Bacteroides species and anaerobic cocci in mixed infection. Surgery 1988;103:107-110

9. Steffen EK, Berg RD, Dietch EA. Comparison of translocation rates of various indigenous bacteria from the gastroin- testinal tract to the mesenteric lymph node. J Infect Dis 1988; 157:1032-1038

10. Bohnen JMA, Matlow AG, Mustard RA, Christie NA, Kavouris B. Antibiotic efficacy in intraabdominal sepsis: a clinically relevant model. Can J Microbiol 1988;34: $323-326$

THE JOURNAL OF INFECTIOUS DISEASES - VOL. 160, NO. 1 - JULY 1989

(C) 1989 by The University of Chicago. All rights reserved. 0022-1899/89/6001-0020\$01.00

\title{
Ribosomal RNA Gene Restriction Patterns Provide Increased Sensitivity for Typing Salmonella typhi Strains
}

\author{
M. Altwegg, F. W. Hickman-Brenner, \\ and J. J. Farmer III
}

\begin{abstract}
From the Department of Medical Microbiology, University of Zurich, Switzerland, and the Enteric Bacteriology Section, Division of Bacterial Diseases, Center for Infectious Diseases, Centers for Disease Control, Atlanta, Georgia
\end{abstract}

To date, epidemiologic associations among strains of Salmonella typhi are based exclusively on phage typing, which may be of limited value if a common phage type is involved. Analysis of ribosomal RNA gene restriction patterns allows separation of most independently isolated strains of identical phage types. The sensitivity of the method is dependent on the restriction enzymes used to digest chromosomal DNA. It was highest for PstI, which separated 16 of 20 strains that belonged to 8 phage types including 3 untypable strains. Three strains differed in their phage types but had identical ribosomal RNA gene restriction patterns. Also, two pairs of strains indistinguishable by phage typing exhibited identical patterns; however, two of these strains were expected to be identical because they were isolated from two patients who were likely exposed to the same source. Ribosomal RNA gene restriction patterns appear to be stable. Thus, the method may complement phage typing and aid in further differentiation of strains.

Typhoid fever is an acute, febrile illness that frequently represents a major public health problem in developing countries and to travelers to these regions. Large outbreaks usually linked to asymptomatic carriers who have excreted Salmonella typhi for years, however, have been reported from developed countries [1]. Bacteriophage typing requiring the presence of the Vi antigen is the method of choice to demonstrate epidemiologic associations among strains of this species [2], but its use is limited to reference

Received for publication 24 October 1988 and in revised form 6 February 1989.

The use of trade names is for identification only and does not imply endorsement by the Public Health Service or by the US Department of Health and Human Services.

Please address requests for reprints to Dr. M. Altwegg, Department of Medical Microbiology, University of Zurich, Gloriastrasse 32, CH-8028 Zurich, Switzerland. laboratories that have all $100+$ necessary phage suspensions available. Also, depending on the geographic location, only a few phage types represent the majority of strains isolated $[3,4]$. For example, nearly $25 \%$ of the strains isolated in the USA belong to phage type $\mathrm{El}$ and up to $80 \%$ of the strains encountered in certain African countries are of phage type A [4]. Therefore, phage typing provides little additional epidemiologic information if the same phage type is found both in patients and in the suspected carrier $[2,3]$.

The specificity of Vi types is determined by the carriage of temperate phages and by the nonlysogenic precursor type [5]. This implies that loss or uptake of a lysogenic phage can result in a change of the phage type. This has been proven experimentally and has been shown to occur naturally, thus complicating epidemiologic analysis [6]. Attempts to de- 
velop other reliable, sensitive, and easy-to-perform typing methods that might complement phage typing have failed because $S$. typhi strains are homogeneous in their phenotype. Multilocus enzyme electrophoresis, although useful for other groups of bacteria such as Legionella pneumophila [7], Escherichia coli [8], or Aeromonas species [9], did not reveal a single difference among 26 strains of diverse geographic origin and phage types with 24 different enzymes that had been analyzed [10]. We describe the variation of $S$. typhi strains with regard to ribosomal RNA (rRNA) gene restriction patterns [11] and their potential as an epidemiologic tool.

\section{Strains and Methods}

Strains. S. typhi strains isolated from humans were selected from the culture collection at the Centers for Disease Control, Atlanta, mainly to represent groups of identical phage type but to be independent from each other otherwise, that is, they were isolated at different geographic locations at differ- ent times (table 1). In addition, two strains were included that were isolated from two patients in the same hospital who had probably been exposed to the same source. Serratia fonticola 3965 was used to provide a molecular weight standard for rRNA gene restriction patterns [11].

Restriction endonuclease analysis and ribosomal RNA gene restriction patterns. For restriction endonuclease analysis and rRNA gene restriction patterns, the method developed by Grimont and Grimont [11] was used with some modifications. Briefly, high-molecular-weight chromosomal DNA was isolated from strains grown on blood agar for $48 \mathrm{~h}$ at $37^{\circ} \mathrm{C}$ by a modified, small-scale version of a published procedure [12]. DNA samples were digested with restriction endonucleases (New England Biolabs, Beverly, Mass), electrophoresed on either $0.8 \%$ or $1.0 \%$ agarose gels in Tris-acetate buffer (0.04 $M$ Tris acetate, $0.002 M$ EDTA, pH 8.0), and stained in ethidium bromide $(1 \mu \mathrm{g} / \mathrm{ml})$ for $20 \mathrm{~min}$. Gels were then photographed and blotted to nitrocellulose according to established procedures [13]. Plas-

Table 1. Typing of Salmonella typhi strains of various phage types by analysis of restriction and rDNA patterns.

\begin{tabular}{|c|c|c|c|c|c|c|c|c|c|}
\hline \multirow[b]{2}{*}{ Strain-year } & \multirow{2}{*}{$\begin{array}{l}\text { Location of } \\
\text { isolation }\end{array}$} & \multirow[b]{2}{*}{ Source } & \multirow[b]{2}{*}{ Phage type } & \multicolumn{3}{|c|}{$\begin{array}{l}\text { Restriction } \\
\text { patterns }\end{array}$} & \multicolumn{3}{|c|}{$\begin{array}{c}\text { Ribosomal DNA } \\
\text { patterns }\end{array}$} \\
\hline & & & & $P s t \mathrm{I}$ & Eco RI & SmaI & PstI & EcoRI & Smal \\
\hline 0486-78 & Massachusetts & Blood & A & A & & A & G & & A \\
\hline $1081-79$ & California & Blood & A & A & & $\mathrm{A}$ & $\mathbf{H}$ & & $\mathrm{C}$ \\
\hline $3018-79$ & New York & Stool & A & A & & $\mathbf{A}$ & $\mathbf{H}$ & & $\mathrm{C}$ \\
\hline $2082-86$ & North Carolina & Blood & $\mathrm{A}$ & A & & $\mathrm{A}$ & $\mathrm{D}$ & & B \\
\hline $2051-87$ & New York & Stool & A & A & & A & I & & B \\
\hline $2835-79$ & Massachusetts & Bile & A (VIII-) & A & & $\mathbf{A}$ & $\mathrm{K}$ & & D \\
\hline $2003-88$ & Alabama & Unknown & A (VIIl-) & A & $\mathrm{B}^{*}$ & A & $\mathrm{C}$ & $\mathrm{B}^{*}$ & $\mathbf{E}$ \\
\hline $1207-84$ & New York & Blood & $A(I I I-)$ & A & & A & $\mathbf{L}$ & & $F$ \\
\hline $0571-78$ & Texas & Blood & E1 & A & & A & $\mathbf{N}$ & & $c$ \\
\hline $0048-80$ & New York & Stool & E1 & A & & & $\mathbf{M}$ & & B \\
\hline $2030-87$ & Florida & Blood & E1 & A & & & $\mathrm{E}$ & & \\
\hline $3036-77$ & Texas & Blood & Degraded Vi/A ${ }^{\dagger}\left(\operatorname{mex}^{r}\right)$ & B & & & $\bar{P}$ & & \\
\hline $0891-79$ & New York & Stool & Degraded Vi/A $\left(\right.$ mex $\left.^{5}\right)$ & $\mathbf{A}$ & & & o & & \\
\hline $2115-87$ & New York & Unknown & Degraded Vi/A $\left(\operatorname{mex}^{s}\right)$ & $\mathbf{A}$ & A & & $E$ & A & \\
\hline $2001-88$ & California & Bile & Untypable & A & A & & A & A & \\
\hline $2004-88$ & California & Bile & Untypable & $\mathbf{A}$ & A & & D & A & \\
\hline $2005-88$ & California & Blood & Untypable & A & A & & $\mathrm{E}$ & A & \\
\hline $2006-88$ & Connecticut & Bile & Degraded Vi (45-, 51-) & A & A & & $\mathrm{F}$ & A & \\
\hline $2007-88$ & Connecticut & Bile & Degraded Vi (45-, 51-) & A & A & & $\mathrm{F}$ & A & \\
\hline $2002-88$ & Pennsylvania & CSF & 46 (atypical) & A & A & & B & A & \\
\hline
\end{tabular}

NOTE. Isolates were epidemiologically related except strains 2006-88 and 2007-88, which were isolated from two patients in the same hospital ward. CSF = cerebrospinal fluid.

* DNA was not cut by EcoRI.

$\dagger$ Degraded Vi/A, degraded Vi approaching A. These strains are sometimes called the "Mexican strain" and occur in the two phenotypes mexr (antibiotic resistant) or $\operatorname{mex}^{s}$ (antibiotic sensitive). 
mid pKK 3535 was used as a probe. This plasmid is a pBR322-derived plasmid containing essentially a ribosomal RNA operon consisting of one copy each of the genes coding for 5S RNA, 16S RNA, 23S RNA, and tRNA ${ }^{\mathrm{Glu}_{2}}$ [14]. Plasmid DNA was labeled using $\left[{ }^{32} \mathrm{P}\right] \mathrm{dCTP}$ (DuPont NEN Research Products, Boston) and a commercial nick translation kit (BRL, Gaithersburg, Md), heat-denatured and hybridized to the filter-bound restriction fragments as described by Maniatis et al. [13] with the following modifications: filters were prehybridized in $6 \times$ standard saline citrate (SSC), $10 \times$ Denhardt solution for $60 \mathrm{~min}$, and in hybridization solution ( $2 \times$ SSC, $5 \times$ Denhardt solution, $0.02 M$ Tris hydrochloride, $\mathrm{pH} 7.4,0.1 \%$ SDS, and $41 \%$ formamide) at room temperature for at least $60 \mathrm{~min}$ before addition of the radioactive probe. Hybridization was done overnight at $37^{\circ} \mathrm{C}$, equivalent to an effective hybridization temperature of $66.5^{\circ} \mathrm{C}$. Filters were then washed as described [9], dried, and autoradiographed for 3-24 h at $-70^{\circ} \mathrm{C}$ using Kodak XOMAT film and two intensifying screens (Kodak, Rochester, NY).

\section{Results}

Restriction endonuclease analysis. Among the 20 strains (17 strains belonging to 7 different phage types and 3 untypable strains), only slight variability could be demonstrated (figure 1 top; table 1). All nine strains digested with restriction endonuclease Smal exhibited the same banding pattern. For the two enzymes EcoRI and Pst the results were similar. Only one strain of each differed in its pattern. Strain 2003-88 was repeatedly resistant to the action of EcoRI, although the DNA was cut by other enzymes, and strain 3036-77, the only strain of that phenotype (mex ${ }^{\mathrm{r}}$, table 1), differed from all other strains by the presence of two high-molecular-weight bands (figure 1 top).

Ribosomal RNA gene restriction patterns. More variability among strains could be demonstrated when restriction fragments were hybridized with radiolabeled DNA complementary to the genes coding for rRNA. Some sequences within these genes are conserved among a wide range of taxonomic groups (including gram-positive and gram-negative organisms) and thus allow hybridization with rRNA isolated from $E$. coli or, as done in this study, with E. coli DNA (cloned in plasmid pBR322) coding for rRNA. Multiple bands are expected because rRNA
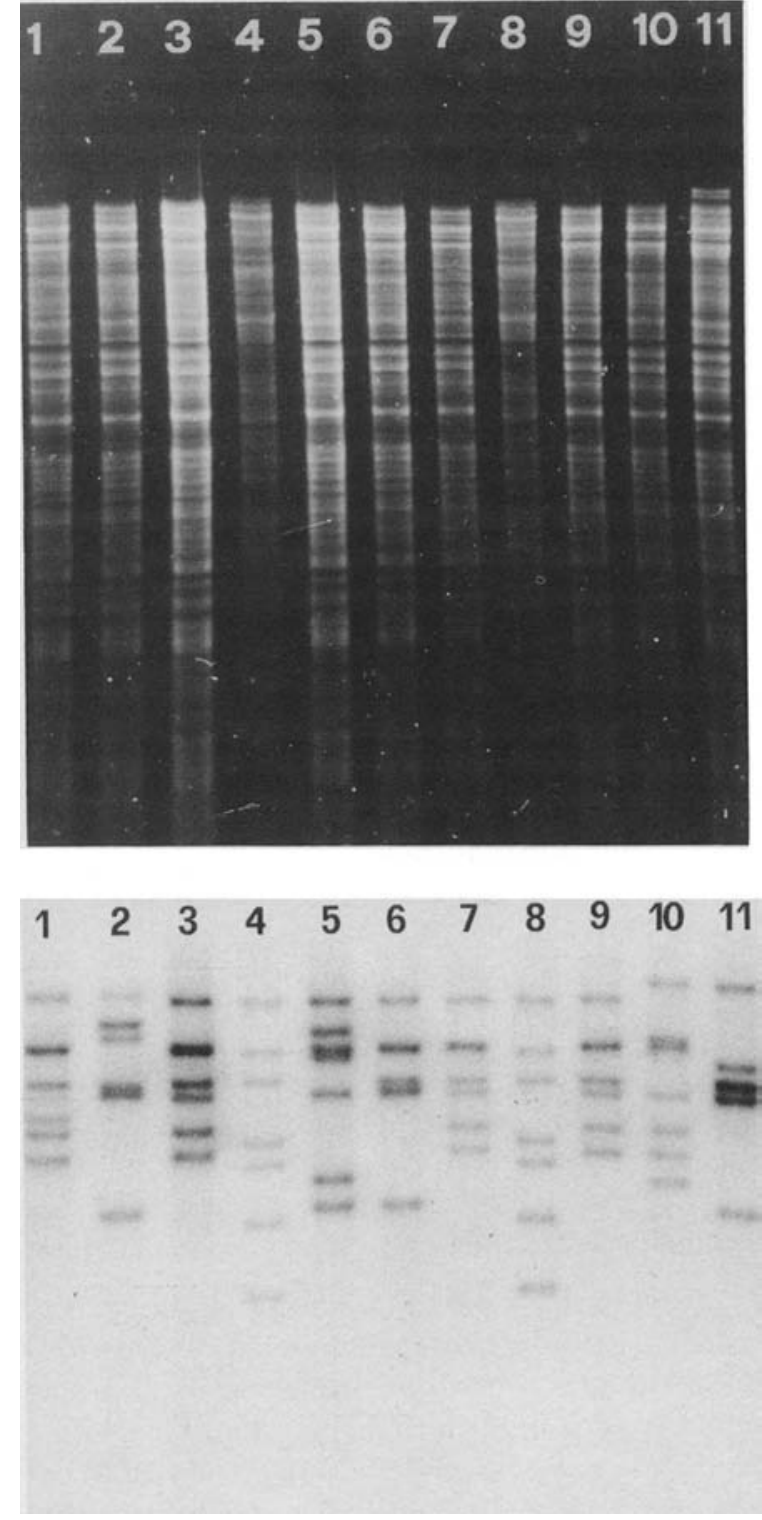

Figure 1. Restriction endonuclease patterns (top) and ribosomal RNA gene restriction patterns (bottom) of $S$. typhi DNA digested with PstI. Lanes 4 and 8, Serratia fonticola DNA digested with HindIII (standard); lane I, strain 0048-80; lane 2, strain 0571-78; lane 3, strain 2030-87; lane 5 , strain 2001-88; lane 6, strain 2004-88; lane 7, strain 2005 88; lane 9, strain 2115-87; lane 10, strain 0891-79; lane 11, strain 3036-77. Strains belong to the following phage types: lanes 1-3, type El; lanes 5-7, untypable; lanes 9-11, degraded Vi approaching A (Mexican strain). Sizes (in base pairs) of fragments generated by digestion of $S$. fonticola with HindIII (lanes 4 and 8 ) are 14,596, 11,853, 10,601, 8520, 7892,6634 , and 5419 (from top to bottom). 
operons are redundant in most bacteria [11]. The variability of patterns is highly dependent on the restriction endonucleases used. EcoRI patterns were determined for five strains belonging to four different phage types and three untypable strains. All were identical except for the strain that was resistant to the action of this enzyme (table 1).

Ten strains of four phage types were analyzed with restriction endonuclease $S \mathrm{mal}$, and only two patterns were not restricted to a single strain (table 1). Strains 2082-86 and 2051-87 (both of phage type A) and strain 0048-80 (phage type E1) were identical (pattern $B$, table 1), as were three strains with pattern $C$ that belonged to either phage type A (two strains) or phage type El (one strain). The two type A strains were isolated in the same year in two different states (California and New York).

The best discrimination among strains provided restriction endonuclease Pstl. For 20 strains analyzed, 16 different patterns were found (table 1, figure 1). Only three groups of strains could not be differentiated. Among these were the two strains of phage type A that were also identical using Smal (see above) and three strains of phage type E1, degraded $\mathrm{Vi} / \mathrm{A}$ ( $\mathrm{mex}^{\mathrm{s}}$, table 1 ), and one that was not typable. Also, the two strains of the same phage type that had been isolated from two patients in the same hospital ward in Connecticut were identical.

\section{Discussion}

Phage typing has been the method of choice for decades to demonstrate epidemiologic associations among isolates of $S$. typhi. However, because this method frequently fails to provide additional information [3], some researchers have attempted to develop methods that would complement phage typing and allow differentiation of nonrelated strains that are of identical phage types [10]. Our results clearly show that the determination of rRNA gene restriction patterns, but not the comparison of restriction patterns, is a technique with the desired sensitivity.

The usefulness of the method depends on the enzyme(s) chosen for the analysis. EcoRI was the least useful of the enzymes tested in this study. All patterns were identical with the exception of a single strain whose DNA was not cut at all. The reason for this phenomenon is unknown. However, it was reproducible and probably not due to impurities in the
DNA preparation because the activity of other enzymes was not affected.

Smal was used with only 10 strains. It was of intermediate sensitivity; two groups of three strains each were not distinguishable. Identical strains did not necessarily belong to the same phage type (table 1).

For the $\mathbf{2 0}$ strains used in this study, PstI proved to be by far the most useful enzyme. Most strains of identical phage types were easily differentiated and differed in one or several bands. Two pairs of strains that were not distinguishable are of special interest. The first two strains, both of phage type A, were isolated in 1979 in two states (California and New York). Neither was distinguishable from the other by SmaI patterns. Because no more epidemiologic information regarding these two infections is available, it can be speculated that the two patients had been exposed to the same source. It is more likely, however, that the methods evaluated here do not allow differentiation of the strains. For the second pair of identical strains, the epidemiologic background is better known. The strains were isolated from two related patients treated in the same hospital, who likely acquired the infection by exposure to a common source.

These two strains were chosen for our analysis to provide some data on the stability of the patterns. The results are consistent with the earlier finding that the patterns for a strain of $E$. coli remained constant after 16 serial subcultures in vitro [15]. The same authors had also shown that all eight colonies isolated from the primary sputum culture of a Pseudomonas cepacia-colonized patient were identical, although colonies of different morphology had been selected. This relative stability is important for typing methods if they are to be applicable in epidemics. The three strains of $P s t I$ pattern E could be differentiated by phage typing but not by rRNA gene restriction patterns, indicating the complementary nature of the two methods.

The specificity of the DNA probe compares well with that using rRNA since the pattern of $S$. fonticola-DNA is identical to that described [11]. In addition, rDNA patterns in Aeromonas [9] are also identical regardless of the protocol used (unpublished data). Therefore, the presence of the entire rRNA operon (plasmid insert) and the two antibiotic-resistant genes (vector pBR322) do not seem to cause any problems under the relatively stringent conditions used for hybridization.

The method described for the typing of $S$. typhi 
strains of fers an increased sensitivity over phage typing. It will be especially useful to analyze epidemics caused by common phage types and for the typing of strains that change phage type due to the loss or uptake of a temperate phage. The option of using the method on a nonradioactive basis (commercial kits for biotinylation of DNA and detection of hybrids are available) makes this method especially promising for use in nonreference laboratories and in developing countries.

\section{References}

I. Taylor JP, Shandera WX, Betz TG, Schraille K, Chaffee L, Lopez L, Henley R, Rothe CN, Bell RF, Blake PA. Typhoid fever in San Antonio, Texas: an outbreak traced to a continuing source. J Infect Dis 1984;149:553-557

2. Anderson ES, Williams REO. Bacteriophage typing of enteric pathogens and staphylococci and its use in epidemiology. J Clin Pathol 1956;9:94-127

3. Hickman-Brenner FW, Farmer JJ III, Regional centers for Salmonella typhi bacteriophage typing in the United States. Bacteriophage types of Salmonella typhi in the United States from 1974 through 1981. J Clin Microbiol 1983; 17:172-174

4. International Committee for Enteric Phage-Typing (ICEPT) The geographical distribution of Salmonella typhi and Salmonella paratyphi $A$ and $B$ phage types during the period I January 1966 to 31 December 1969. J Hyg (Lond) 1973;71:59-84

5. Anderson ES, Felix A. The Vitype-determining phages carried by Salmonella typhi. J Gen Microbiol 1953;9:65-88

6. Borecká J. Púčeková G, Bolchová S, Hlančová Z, Suchánek
M. To the question of stability of Salmonella typhi phage types. J Hyg Epidemiol Microbiol Immunol 1973;17: 202-207

7. Selander RK, McKinney RM, Whittam TS, Bibb WF, Brenner DJ, Nolte FS, Pattison PE. Genetic structure of populations of Legionella pneumophila. J Bacteriol 1985;163: 1021-1037

8. Caugant DA, Levin BR, Ørskov I, Ørskov F, Svanborg-Eden C, Selander RK. Genetic diversity in relation to serotype in Escherichia coli. Infect Immun 1985;49:407-413

9. Altwegg M, Altwegg-Bissig R, Demarta A, Peduzzi R, Reeves MW, Swaminathan B. Comparison of four typing methods for Aeromonas species. J Diarrhoeal Dis Res (in press)

10. Reeves MW, Evins GM, Heiba AA, Plikaytis BD, Farmer JJ 1II. Clonal nature of Salmonella typhi and its genetic relat. edness to other salmonellae as shown by multilocus enzyme electrophoresis, and proposal of Salmonella bongori: comb. nov. J Clin Microbiol 1989;27:313-320

11. Grimont F, Grimont PAD. Ribosomal ribonucleic acid gene restriction patterns as potential taxonomic tools. Ann Inst Pasteur Microbiol 1986;137B:165-175

12. Brenner DJ, McWhorter AC, Knutson JKL, Steigerwalt AG. Escherichia vulneris: a new species of Enterobacteriaceae associated with human wounds. J Clin Microbiol 1982; 15:1133-1140

13. Maniatis T, Fritsch EF, Sambrook J. Molecular cloning, a laboratory manual. Cold Spring Harbor, NY: Cold Spring Harbor Laboratory, 1982

14. Brosius J, Ullrich A, Raker MA, Gray A, Dull TJ, Gutell RR, Noller HF. Construction and fine mapping of recombinant plasmids containing the $r r n B$ ribosomal RNA operon of $E$. coli. Plasmid 1981;6:112-118

15. Stull TL, LiPuma JJ, Edlind TD. A broad-spectrum probe for molecular epidemiology of bacteria: ribosomal RNA. J Infect Dis 1988;157:280-286 